\title{
Salinity and ionic composition of the shallow astatic soda pans in the Carpathian Basin
}

\author{
E. Boros ${ }^{1 *}$, Zs. Horváth ${ }^{2}$, G. Wolfram ${ }^{3}$ and L. Vörös ${ }^{1}$ \\ ${ }^{1}$ Balaton Limnological Institute, Centre for Ecological Research of the Hungarian Academy of Sciences, P.O. Box 35, H-8237 \\ Tihany, Hungary \\ 2 WasserCluster Lunz, Dr. Carl Kupelwieser Promenade 5, AT-3293 Lunz am See, Austria \\ 3 DWS Hydro-Ökologie GmbH, Zentagasse 47/5, -1050 Wien, Austria
}

Received 22 June 2013; Accepted 4 November 2013

\begin{abstract}
We investigated the chemical characteristics of the astatic soda pans in the Carpathian Basin based on comprehensive new and archive data. Analysed parameters were salinity and ionic composition. The most frequent type of soda waters was the basic alkaline type $\left(\mathrm{Na}-\mathrm{HCO}_{3}\right)$ that represented more than half of the natural soda pans. Besides 11 subtypes occurred. The second and third most frequent types were the chloride $(13 \%)$ and sulphate subtypes $(11 \%)$, with the secondary dominance of these anions. The other subtypes meant $<4 \%$ of the pans. Magnesium sometimes occurred as a secondary dominant cation beside sodium. Until now, this subtype of soda waters has not been published in any part of the world, because of the general rule of soda lake formation (depending on low levels of magnesium and calcium). We found a regionally constant correction factor [Salinity $\left(\mathrm{mg} . \mathrm{L}^{-1}\right)=0.8 \times$ El.Cond. $\left(\mu \mathrm{S} . \mathrm{cm}^{-1}\right)$ ] for confidentially estimating salinity from electrical conductivity in these habitats. Salinity varied between sub- $\left(0.5-3\right.$ g.L $\left.{ }^{-1}\right)$ and hypersaline $\left(>50\right.$ g. $\left.\mathrm{L}^{-1}\right)$ ranges, with its mean value $\left(\sim 4\right.$ g. $\left.\mathrm{L}^{-1}\right)$ in the hyposaline range $\left(3-20 \mathrm{~g} . \mathrm{L}^{-1}\right)$. The basic alkaline type had random geographical distribution, while the other subtypes were restricted to certain regions of the Basin. The high number of subtypes reflects the high chemical diversity of alkaline soda pans in the relatively small territory of the Carpathian Basin.
\end{abstract}

Key words: Soda pan / ionic composition / alkaline / astatic / Carpathian Basin

\section{Introduction}

Athalassohaline waters are divided into three extreme types based on the dominance of carbonate, chloride or sulphate anions. Soda dominated waters are characterized by large amounts of sodium carbonate and usually have lower salinity (in hyposaline range), but they have high alkalinity $(\mathrm{pH}>9)$, which clearly distinguishes them from other athalassohaline waters (Hammer, 1986).

Highly alkaline lakes are confined to specific geographic regions: examples are known from North, Central and South America, Europe, Asia (notably in Siberia, Outer Mongolia and Tibet), Australia and throughout Africa (Löffler, 1971; Hammer, 1986; Grant, 2006). Nevertheless, moderately alkaline water can be found

*Corresponding author: szikesviz@gmail.com with co-occurrence of $\mathrm{Na}, \mathrm{Ca}, \mathrm{HCO}_{3}, \mathrm{Cl}$, and $\mathrm{SO}_{4}$ ions in the Cristo lagoon on Neogene deposits in northern Spanish Meseta (Jambrina et al., 2013). Due to their lower salinity, biodiversity of soda waters is generally higher than other continental saline waters (Williams, 1998; Grant, 2006). Recently, there is a growing emphasis also on the extreme alkaliphile microbiological diversity of soda lakes corresponding with the alkaline chemistry (Grant, 2006).

Most authors found only a few basic chemical types (4-5) of saline waters (brine type) with certain combinations of $\mathrm{Na}, \mathrm{Mg}, \mathrm{Cl}, \mathrm{SO}_{4}, \mathrm{HCO}_{3}$ and $\mathrm{CO}_{3}$ (e.g., Eugster and Hardie, 1978; Williams, 1998; Warren, 2006). Hammer (1986) divided them into six types $\left(\mathrm{Na}-\mathrm{HCO}_{3}\right.$, $\mathrm{NaCl}, \mathrm{Ca}-\mathrm{HCO}_{3}, \mathrm{Mg}-\mathrm{HCO}_{3}, \mathrm{Na}-\mathrm{SO}_{4}, \mathrm{Mg}-\mathrm{SO}_{4}$ ) based on the 25 equivalence per cent $(\mathrm{e} \%)$ dominance of the cations and anions, while according to multiple ion dominances, many subtypes of saline waters (at least 20-25) were described all over the world. 
If groundwater chemistry is dominated by bicarbonate $\left(\mathrm{HCO}_{3} \gg \mathrm{Ca}+\mathrm{Mg}\right)$, there is an evidence that soda lake formation is dependent on low levels of dissolved calcium and magnesium among the cations as alkaline carbonates fall out of solution, which determines soda lake genesis (Grant, 2006; Warren, 2006).

The microbial population presumably influences the kinetics of $\mathrm{CO}_{2}$ addition or depletion in the system, contributing to trona formation (Grant, 2006). Recently, Warren (2006) provided a detailed hydrological classification of nonmarine (athalassohaline) brines and associated evaporite minerals all over the world. He described the hydrogeological genesis of alkaline waters and the phase chemistry of sodium carbonate. The $\mathrm{CO}_{2}$ content of the gas phase and temperature regulate the processing of natron (sodium carbonate: $\mathrm{Na}_{2} \mathrm{CO}_{3} \times 10 \mathrm{H}_{2} \mathrm{O}$ ) and trona [trisodium hydrogendicarbonate dihydrate: $\mathrm{Na}_{3}\left(\mathrm{CO}_{3}\right) \times$ $\left(\mathrm{HCO}_{3}\right) \times 2 \mathrm{H}_{2} \mathrm{O}$ ] precipitation in a saturated solution. It means that trona is in the stabile phase within the range of $25-60^{\circ} \mathrm{C}$, for example in the tropical soda Lake Magadi (Kenya). Natron is the most common evaporite mineral of the soda lakes in the temperate zone, while the high level of $\mathrm{CO}_{2}$ (as in the Archean atmosphere) favoured the widespread co-occurrence of nahcolite with trona along with halite.

Numerous chemical data have been published on the permanent soda waters in the Carpathian Basin. The Lake Neusiedl/Fertö (in Austria and Hungary) and the Lake Velence (in Hungary) are relatively well-known shallow lakes with soda water (Löffler, 1979). The relatively deep ( 3-4 m), permanent Lake Szelid (in Hungary) originally also had soda dominated water (Donászy, 1959).

The chemical characteristics of the astatic soda pans were studied in different regions of the Carpathian Basin in the last 10-20 years, e.g., well-studied pans can be found in Seewinkel by the eastern shore of the Lake Neusiedl/ Fertö (Oberleitner et al., 2006) and there are also a few in Hungary (Boros and Vörös, 2010), while recently only Petrović (1981) analysed the chemistry of saline lakes in Serbia.

Although there is much data about the chemical composition of soda waters in the Carpathian Basin, no comprehensive and relatively actual survey is available regarding the ionic composition of the astatic soda pans. The aim of this study was to fill the gap in this knowledge; therefore, we surveyed and categorized the chemical composition of all natural astatic soda pans in the Carpathian Basin based on several new and some selected archive data.

\section{Methods}

\section{Study area}

Soda pans were formed on various geological substrates by specific climatic, geologic and hydrologic environment in the Carpathian Basin, which were influenced by human impact in the last two centuries. At the end of Pleistocene and the beginning of Holocene due to the dry and cold climate, wind deflation processed eolic sand and loess sedimentation from alluvial deposit. The oldest known Hungarian paleo-sodification sediment is of Pleistocene age, but the main and most extensive sodification started at the beginning of the Holocene period. The calcite content is the highest in sediment of the Danube Valley (due to erosion from the Alps), while alluvial sediment of the River Tisza has lower calcite content. Present-day soda lakes and pans can be found on the plain region of the Carpathian Basin on sand, loess or alluvial substrate, where groundwater is permanently close to the surface. The evaporative continental and sub-continental climate is also a key factor in the sodification process beside sediment composition, structure and groundwater supply (Boros, 1999). Under these characteristic ecological conditions, soda waterbodies support characteristic flora and fauna. Many of their euryhaline or halophilic species have wide salinity tolerance and some characteristic natronophilic or alkaliphilic species also tolerate high alkalinity (e.g., Metz and Forró, 1989; Horváth et al., 2013a). The high fluctuations of water level and salinity cause notable seasonal changes in the alkaline communities. Marshland (Bolboschoeno-Phragmitetum) and characteristic wet meadow vegetation (Lepidio crassifoliiPuccinellietum limosae) are found around the shoreline, while submerged macrophytes are sparse or absent in the open water (Boros, 1999). More details on the ecology and overall characteristics of soda pans are recently also published by Horváth et al. (2013a, 2013b).

The study area was the total lowland territory of the Carpathian Basin, where the astatic soda pans are located. This involved the survey of the Seewinkel region of Austria, the Great Hungarian Plain of Hungary and the connected Vojvodina region of Serbia. We did not succeed in finding any existing natural soda pans in this geographical part of other countries e.g., Romania, Ukraine, Croatia, etc.

The most important ecological criteria of the investigated natural astatic soda pans are listed below:

- Shallow astatic open water bodies with bare pan bed (completely lack of marshland or grassland vegetation);

- Annual average of salinity exceeding 1 g. $\mathrm{L}^{-1}$;

- The presence of soda indicator species or characteristic flora and fauna.

Only those pans were involved that complied with these criteria. Man-made or semi-natural (e.g., restored, reconstructed) pans were not included in the present study.

\section{Chemical and data analysis}

The evolution of the soda pans and lakes is related to the lack of alkaline earth cations compared with the richness of bicarbonate, a shallow depressed structure with a closed non-leaking drainage basin and the high 
evaporation rate that exceeds the inflow. Based on their turbidity, soda pans can be divided into two main ecologically representative types: the "turbid-white" and the "non-turbid-coloured" soda pans (Megyeri, 1979). The "turbid-white" type is dominated by large amounts of suspended inorganic (clay) particles that generally cause very high turbidity and light grey-white colour of the water. The "non-turbid-coloured" type has much less suspended particles and is rather dominated by dissolved brown-black coloured (humic) substances. In the present study, we did not distinguish the different types of soda pans mentioned above (e.g., by turbidity or coloured substances). We had summed up the available archive chemical data before the field experiment. Reliable data available from the last 20 years was included in our database and the completely unknown sites were sampled during this investigation. The source of archive data are indicated in Appendix 1. Water samples were taken from each natural pan in the late spring/early summer seasons of 2009-2010 (the exact dates are listed in Appendix 1), which fulfilled the ecological criteria listed above. The sampling sites were selected in the deepest parts of open water bodies to avoid the effect of shoreline macrovegetation and other potential modifying factors. Samples were taken with a plastic jug from the surface, middle and deeper layers of the water column and combined to form a composite sample. Water depth was also measured at the sampling sites. An additional cup of freshly collected sample of water was brought to the shoreline and measured with a "WTW MultiLine P4" field instrument on the spot.

Electrical conductivity (EC) was measured with a TetraCon 325 electrode, while salinity was calculated from conductivity (after Freeze and Cherry, 1979).

The total concentration of the eight ions determines the salinity. According to our calibrations, we concluded that the constant of 0.8 is a reliable correction factor to survey the salinity from conductivity in the characteristic soda dominated waters and consequently applied this factor for calculating the salinity values presented in this study.

The $\mathrm{pH}$ was measured with a SenTix 41 and the oxygen concentration was measured with a CellOx-325 electrode.

The majority of pans (exceptions are those for which archive data were available) were visited at least two times between 2009 and 2010, once in early spring and once in late spring/early summer for the adequate determination of their conductivity range. It is usually the lowest after snow melting and the highest before drying out in summer. The water depth, open water surface, $\mathrm{pH}$, dissolved oxygen content and salinity were also determined based on several field observations, while ionic composition was always analysed by using the early summer samples.

The samples were transported into the laboratory as soon as possible and were filtered through GF5 glass fibre filters. The ion concentrations were measured according to the Hungarian standard methods (MSZ). For cations ( $\mathrm{K}, \mathrm{Na}, \mathrm{Ca}, \mathrm{Mg}$ ), samples were prepared according to the MSZ 1484-3:1998 and analysed with the EPA 6020 standard method of inductively coupled plasma mass
Table 1. The main limnological characteristics of the investigated natural soda pans (2009-2010).

\begin{tabular}{lcrrr}
\hline$n=165$ & Average & Min. & Max. & \multicolumn{1}{c}{ SD } \\
\hline Open water surface (ha) & 23.8 & 0.2 & 198.1 & 43.6 \\
Water depth (cm) & 25.6 & 2.0 & 100.0 & 18.9 \\
Electric conductivity $\left(\mu \mathrm{S.cm}^{-1}\right)$ & 5.5 & 0.6 & 76 & 8.1 \\
Salinity $\left(\mathrm{g} . \mathrm{L}^{-1}\right.$ ) & 4.4 & 0.5 & 60.8 & 6.5 \\
pH & 9.4 & 7.7 & 10.4 & 0.5 \\
Dissolved oxygen (\%) & 107.4 & 28.4 & 444.0 & 39.5 \\
\hline
\end{tabular}

spectrometry (ICP-MS). Chloride ion concentration was determined by the argentometric method (MSZ 44815:1982). Sulphate ion was precipitated in a strongly acid medium with barium chloride and the resulted turbidity was measured photometrically at $405 \mathrm{~nm}$ and compared with standard solutions (MSZ 12750-16:1998). Alkalinity was determined by titration method and the concentrations of $\mathrm{HCO}_{3}, \mathrm{CO}_{3}$ and $\mathrm{OH}$ ions were calculated according to the MSZ 448-11:1986.

As the proportion of carbonate and bicarbonate strongly depends on $\mathrm{pH}$, carbonate ions only occur if $\mathrm{pH}$ exceeds the 8.5 threshold value. The ordering of ionic composition was carried out based on the method of Hammer (1986) with a $25 \mathrm{e} \%$ threshold for each of the four cations and anions, while the correlation matrix among the anions were performed on the equivalent mass (mg) of each ion.

Statistical analyses were performed with Statistica for Windows software. In the case of variables with nonnormal distribution (salinity, $\mathrm{pH}$ ) testing the differences in salinity and $\mathrm{pH}$ among the different ionic compositions the non-parametric Kruskal-Wallis test that was used with significance level of $P<0.05$.

The ionic composition of the different chemical types of soda pans is also demonstrated graphically on the traditional Maucha ion field diagram (Maucha, 1932).

The size estimation of the pans was carried out with manual digitization on the screen based on georeferred GoogleEarth aerial photographs. We used ESRI ArcMap 10 GIS software for this process.

\section{Results}

The main limnological characteristics of the investigated soda pans are summarized in Table 1. The investigated pans in the Carpathian Basin were relatively small ( $23.8 \mathrm{ha})$ and very shallow $(\sim 0.25 \mathrm{~m})$ astatic standing waters with a high ratio of open water, but the standard deviations of both parameters were relatively high. The year 2009 was dry, and as a result, most astatic soda pans dried out by the end of June, while 2010 was relatively wet and hence, none of the pans dried out completely during that year. Although the average salinity of the soda pans was in the hyposaline range $\left(\sim 4\right.$ g. $\left.\mathrm{L}^{-1}\right)$ according to Hammer's (1986) categorization, the minimum and maximum data of salinity also covered 

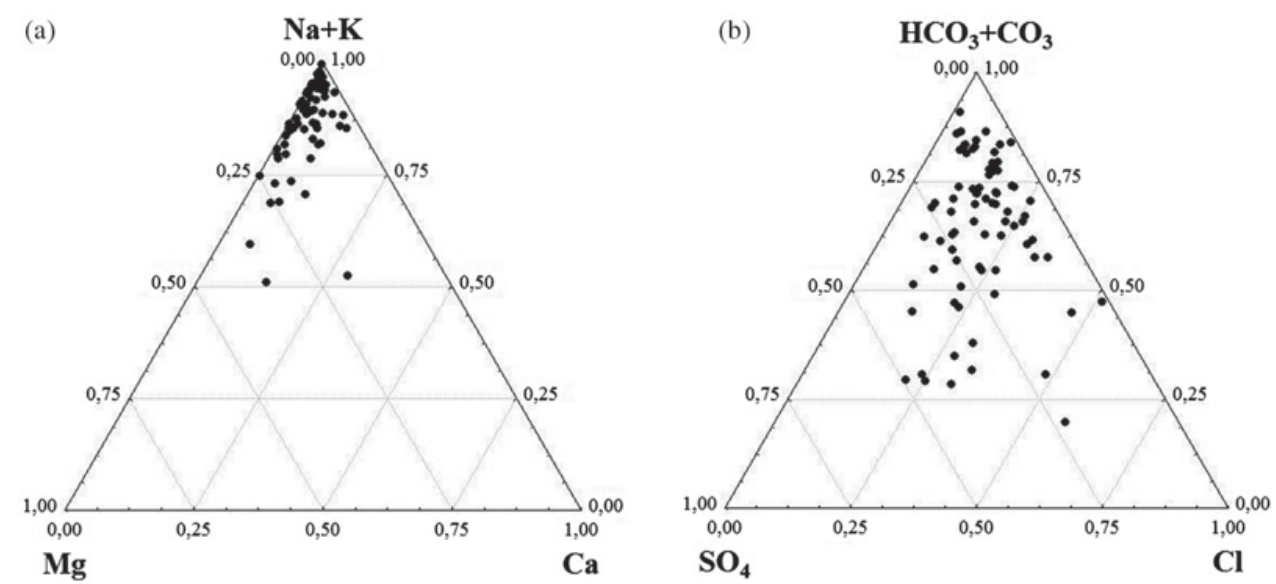

Fig. 1. The general ternary diagrams of the investigated soda pans (each point represents a pan).

the sub- $\left(0.5-3\right.$ g. $\left.\mathrm{L}^{-1}\right)$ and hypersaline $\left(>50\right.$ g. $\left.\mathrm{L}^{-1}\right)$ ranges. The mean of $\mathrm{pH}$ was moderately alkaline $(\sim 9.4)$ and the standard deviation was also relatively low. The dissolved oxygen saturation was balanced $(\sim 107.4 \%)$, but there was a huge gap between the minimum $(28.4 \%)$ and maximum (444\%!) values.

The conventional ternary diagrams of the investigated soda pans are presented in Figure 1. The diagrams demonstrate that the cation composition is dominated by sodium and is simpler than the anion series, where contributions are widely distributed as many different combinations can be observed among the three components. The topography, salinity and $\mathrm{e} \%$ data of the eight cations and anions of each investigated natural soda pan are summarized in Appendix 1.

The conductivity relationships with the total ion concentration was tested by 12 different concentration levels of $\mathrm{NaHCO}_{3}$ solution (range: $100-10000 \mathrm{mg} . \mathrm{L}^{-1}$ ) in the laboratory, and the following calibration equation formula was found (1):

$$
\begin{gathered}
\text { Total ions }\left(\mathrm{g} . \mathrm{L}^{-1}\right)=0.849 \times \mathrm{EC}\left(\mathrm{mS} . \mathrm{cm}^{-1}\right)+186 \\
r^{2}=0.936 ; \quad r=0.967 ; \quad P<0.0001 ; \quad n=12
\end{gathered}
$$

We also tested the calibration with the concentration of the sum of the eight ions $\left(\mathrm{Na}, \mathrm{K}, \mathrm{Ca}, \mathrm{Mg}, \mathrm{SO}_{4}, \mathrm{Cl}, \mathrm{HCO}_{3}\right.$, $\mathrm{CO}_{3}$ ) with original water from the pans, and the following calibration equation formula was found (2):

$$
\begin{gathered}
\text { Total ions }\left(\mathrm{g} . \mathrm{L}^{-1}\right)=0.792 \times \mathrm{EC}\left(\mathrm{mS} . \mathrm{cm}^{-1}\right)+179 \\
r^{2}=0.936 ; \quad r=0.967 ; \quad P<0.0001 ; \quad n=69
\end{gathered}
$$

According to the $25 \mathrm{e} \%$ threshold of each of the eight cations and anions, 12 different chemical types of ionic composition can be identified, which are summarized in Table 2. The Maucha ion field diagrams of the most frequent ( $90 \%$ of all surveyed pans) chemical types of soda pans are presented in Figure 2.

The most frequent type of soda water was the basic alkaline type $\left(\mathrm{Na}-\mathrm{HCO}_{3}\right)$, that comprised more than half $(58 \%)$ of all natural soda pans (Table 2). The distribution of the basic $\left(\mathrm{Na}-\mathrm{HCO}_{3}\right)$ and other chemical subtypes of
Table 2. The chemical types of soda pans in the Carpathian Basin, together with the number of representatives $(\mathrm{N})$ and

\begin{tabular}{|c|c|c|}
\hline Types & $N$ & Frequency $(\%)$ \\
\hline 1. $\mathrm{Na}, \mathrm{HCO}_{3}$ & 46 & 58 \\
\hline 2. $\mathrm{Na}, \mathrm{HCO}_{3}>\mathrm{Cl}$ & 10 & 13 \\
\hline 3. $\mathrm{Na}, \mathrm{HCO}_{3}>\mathrm{SO} 4$ & 9 & 11 \\
\hline 4. $\mathrm{Na}, \mathrm{Cl}>\mathrm{HCO}_{3}$ & 3 & 4 \\
\hline 5. $\mathrm{Na}, \mathrm{SO}_{4}>\mathrm{Cl}>\mathrm{HCO}_{3}$ & 2 & 2.5 \\
\hline 6. $\mathrm{Na}, \mathrm{SO}_{4}>\mathrm{HCO}_{3}$ & 2 & 2.5 \\
\hline 7. $\mathrm{Na}, \mathrm{SO}_{4}>\mathrm{HCO}_{3}>\mathrm{Cl}$ & 2 & 2.5 \\
\hline 8. $\mathrm{Na}>\mathrm{Mg}, \mathrm{HCO}_{3}$ & 2 & 2.5 \\
\hline 9. $\mathrm{Na}, \mathrm{Cl}>\left(\mathrm{HCO}_{3}\right)$ & 1 & 1 \\
\hline 10. $\mathrm{Na}, \mathrm{HCO}_{3}>\mathrm{SO}_{4}>\mathrm{Cl}$ & 1 & 1 \\
\hline 11. $\mathrm{Na}>\mathrm{Ca}, \mathrm{HCO}_{3}$ & 1 & 1 \\
\hline 12. $\mathrm{Na}>\mathrm{Mg}, \mathrm{HCO}_{3}>\mathrm{SO}_{4}$ & 1 & 1 \\
\hline Sum & 80 & 100 \\
\hline
\end{tabular}
their frequency among the pans. Bold letters indicate the three most frequent types, which geographical distributions are presented in Figure 3.

soda pans within the Carpathian Basin are demonstrated in Figure 3. The basic type was almost randomly distributed on the plain areas of the Basin, while the subtypes were restricted to certain regions.

Anions were relatively variable, while the cation composition was more uniform with the dominance of sodium. The second (13\%) and third most frequent (11\%) subtypes contained chloride and sulphate, respectively, as secondary anions besides hydrogen-carbonate. In the case of these subtypes, some geographical pattern could be observed. For example, the representatives of subtype II were concentrated to the Danube Valley in the central part of Hungary and some other scattered parts of the Great Hungarian Plain, together with a few in Seewinkel. On the contrary, subtype III is rather frequent in Seewinkel, while other representatives are located in the Hungarian and Serbian plain areas. The basic type and the above mentioned two subtypes comprise $81 \%$ of the total investigated soda pans. 

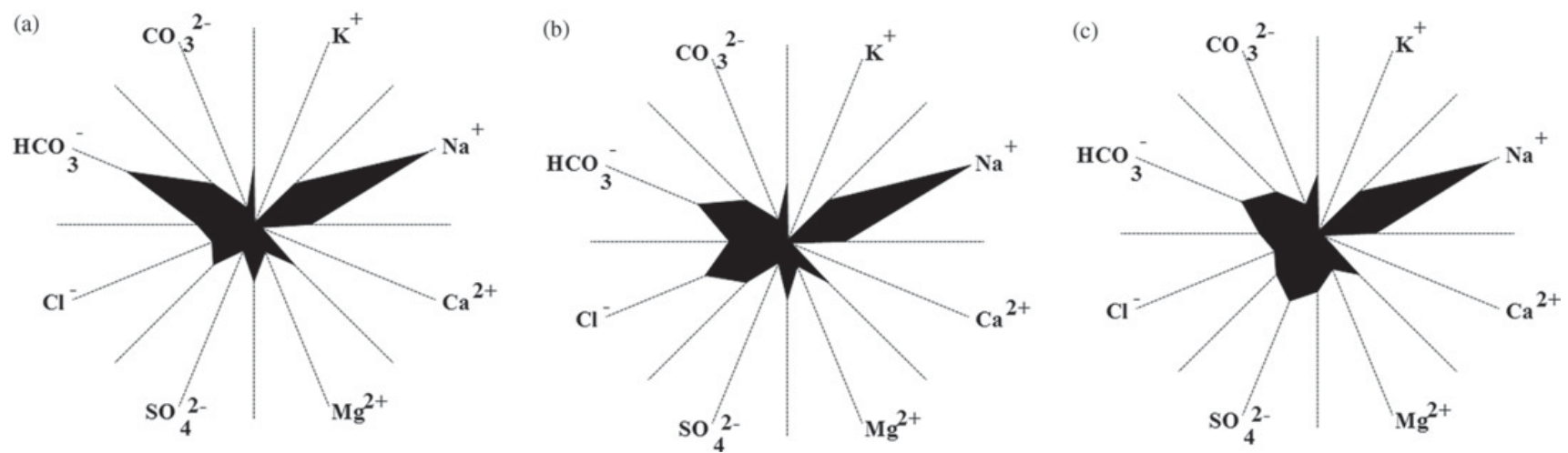

Fig. 2. The Maucha ion field diagrams of the most frequent chemical types of soda pans. (a) $\mathrm{Na}, \mathrm{HCO}_{3}$. (b) $\mathrm{Na}_{2} \mathrm{HCO}_{3}>\mathrm{Cl}$ (c) $\mathrm{Na}$, $\mathrm{HCO}_{3}>\mathrm{SO}_{4}$.

The next five mixed subtypes were much less frequent (3-4\%) than the three main categories. These subtypes represented mixed groups in their anion composition, due to different combinations of sulphate, chloride, hydrogen, carbonate and hydrogen-carbonate besides the primary importance of chloride and sulphate. Furthermore, subtype VIII even contained magnesium among the cations. The representatives of these subtypes were widely scattered in the Carpathian Basin, except for the eastern part of Hungary.

The last four subtypes were also mixed regarding both anions and cations, and they had only one representative, respectively, which indicated their rarity. Among them, there was a simple sodium-chloride dominated pan, where hydrogen-carbonate contribution was $>25 \mathrm{e} \%$, and therefore, it cannot be regarded as real characteristic soda water. Magnesium and calcium also occurred among the cations of the subtypes XI and XII.

As can be seen the correlation matrix of equivalent mass (mg) of ions in Table 3, there were no significant positive correlations among the sodium and other cations, but $\mathrm{Na}$ cation showed significant correlations with all other anions. The $\mathrm{K}$ cation correlated positively with $\mathrm{Mg}$, $\mathrm{SO}_{4}$ and $\mathrm{Cl}$ ions. Ca cations had no significant correlation with any other ions, and $\mathrm{Mg}$ correlated significantly only with $\mathrm{SO}_{4}$. There were significant positive correlations among the $\mathrm{Cl}-\mathrm{SO}_{4}, \mathrm{Cl}-\mathrm{HCO}_{3}, \mathrm{Cl}-\mathrm{CO}_{3}, \mathrm{SO}_{4}-\mathrm{CO}_{3}$ and the most widespread $\mathrm{HCO}_{3}-\mathrm{CO}_{3}$ ion pairs within the anion pool.

Although chloride and sulphate may also be dominant ions besides carbonate and hydrogen-carbonate, there were no significant differences neither in salinity [Kruskal-Wallis test: $H_{(2, N=129)}=7.420 ; \quad P=0.245$; $\left.\chi^{2}=4.286 ; d f=2 ; P=0.117\right]$, nor in $\mathrm{pH}$ [Kruskal-Wallis test: $H_{(2, N=123)}=1.972 ; \quad P=0.373 ; \quad \chi^{2}=1.881 ; \quad d f=2$; $P=0.391]$ among the basic type and the two most important subtypes.

\section{Discussion}

In the soda pans, salinity ranges between sub$\left(0.5-3\right.$ g. $\left.\mathrm{L}^{-1}\right)$ and hypersaline $\left(>50\right.$ g.L $\left.{ }^{-1}\right)$ levels, but the average $\left(\sim 4\right.$ g. $\left.\mathrm{L}^{-1}\right)$ rather stays in the hyposaline range $\left(3-20\right.$ g. $\left.\mathrm{L}^{-1}\right)$. This is attributable to the seasonally highly variable water level of the pans. Natural soda pans in the Carpathian Basin had indeed sodium dominated water, although at some sites, magnesium also represented $>25 \mathrm{e} \%$ of the cations.

The most common (58\%) and geographically most widely distributed alkaline ionic composition is the basic soda type-water in the Carpathian Basin. It is in agreement with Hammer's (1986) worldwide survey on soda water distribution (that resulted in the $54 \%$ contribution of the basic alkaline type), although he only recorded a minority of all soda lakes of the world. Nevertheless, other authors rather reported mixed subtypes of soda waters (mainly coupled with $\mathrm{SO}_{4}$ and $\mathrm{Cl}$, e.g., Grant, 2006; Warren, 2006). Our results are similar to these studies as the second and third most frequent pans are the $\mathrm{Na}-\mathrm{HCO}_{3}>\mathrm{Cl}(13 \%)$ and $\mathrm{Na}-\mathrm{HCO}_{3}>\mathrm{SO}_{4}(11 \%)$ subtypes in the Carpathian Basin. The other nine subtypes had less importance, as they comprised together only $18 \%$ of the investigated pans.

The lack of correlations between sodium and other cations demonstrated the dominance of $\mathrm{Na}$ ion in the cation pool. Additionally, the strongest correlations between the anions showed the importance of $\mathrm{HCO}_{3}+\mathrm{CO}_{3}$ ions in the anion pool.

Magnesium occasionally occurred as a secondary dominant cation beside sodium, and sometimes dissolved calcium was also present in a predominant proportion in these chemical types. This proved to be a completely unknown subtype of soda waters all over the world, since soda lake formation depends on low levels of magnesium and calcium (Grant, 2006; Warren, 2006). In contrast with the basic alkaline type of soda pans, subtypes demonstrate a visible geographical pattern, which is probably determined by local hydrogeological characteristics (deposits and inflow of groundwater etc.). The demonstrated basic type with the 11 subtypes of alkaline waters represent all formerly known types of soda waters over the world, moreover, these are supplemented with the magnesium types. This diverse ionic composition of soda pans can be explained by their development on various geological substrates by specific climatic, geologic and hydrologic 


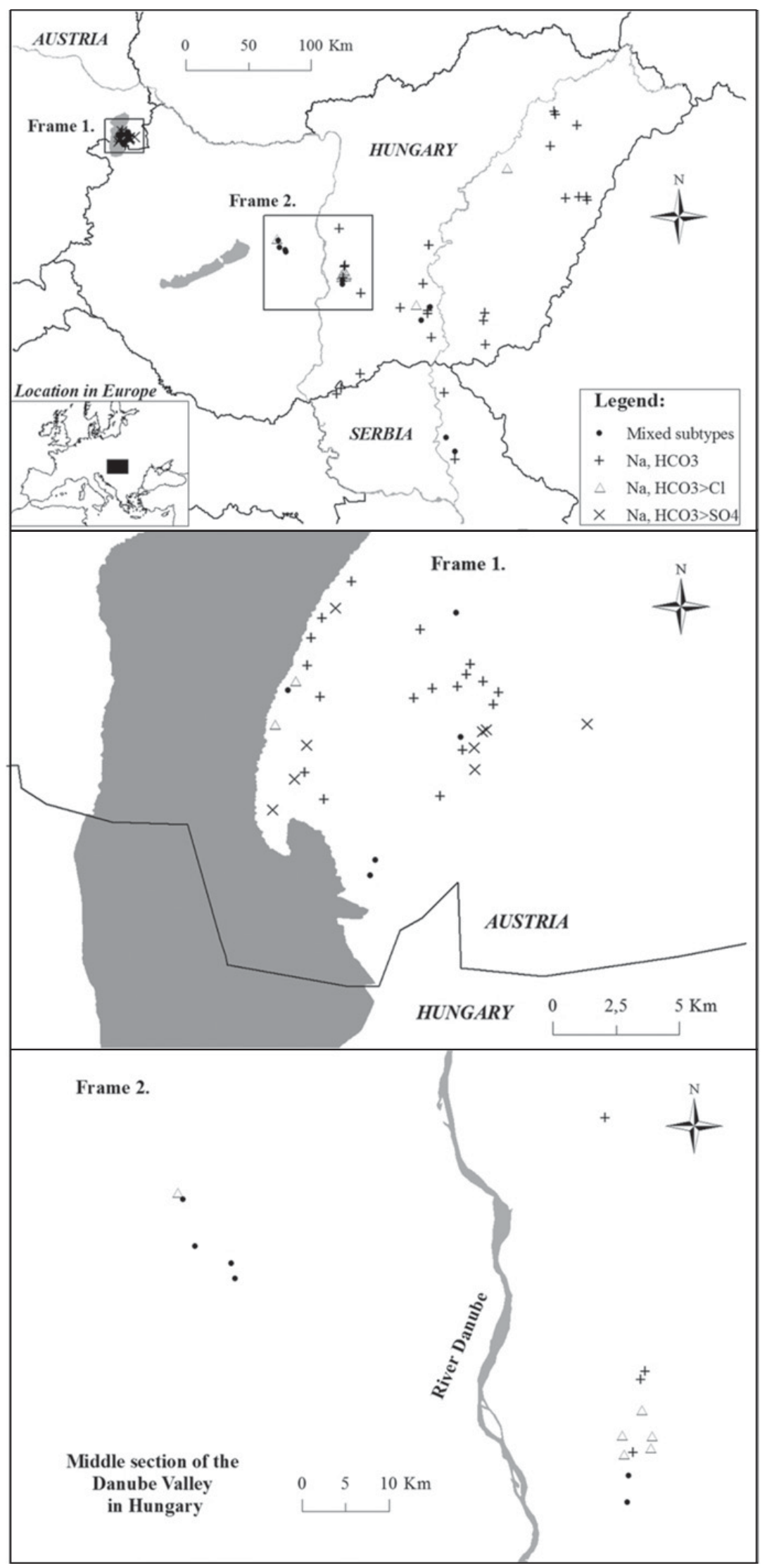

Fig. 3. Geographical distribution of the most frequent chemical types of soda pans within the investigated Carpathian Basin area (Central Europe). 
Table 3. The correlation matrix $\left(R^{2}\right.$ values) of equivalent mass $(\mathrm{mg})$ of ions. Significant correlations $(P<0.05)$ are indicated with bold letters.

\begin{tabular}{|c|c|c|c|c|c|c|c|c|}
\hline & $\mathrm{K}$ & $\mathrm{Na}$ & $\mathrm{Ca}$ & $\mathrm{Mg}$ & $\mathrm{SO}_{4}$ & $\mathrm{Cl}$ & $\mathrm{HCO}_{3}$ & $\mathrm{CO}_{3}$ \\
\hline$\overline{\mathrm{K}}$ & 1.00 & 0.47 & -0.20 & 0.62 & 0.65 & 0.52 & 0.30 & 0.34 \\
\hline $\mathrm{Na}$ & & 1.00 & -0.29 & 0.15 & 0.74 & 0.81 & 0.81 & 0.90 \\
\hline $\mathrm{Ca}$ & & & 1.00 & -0.01 & -0.17 & -0.26 & -0.20 & -0.25 \\
\hline $\mathrm{Mg}$ & & & & 1.00 & 0.51 & 0.37 & 0.07 & -0.02 \\
\hline $\mathrm{SO}_{4}$ & & & & & 1.00 & 0.71 & 0.46 & 0.53 \\
\hline $\mathrm{Cl}$ & & & & & & 1.00 & 0.53 & 0.63 \\
\hline $\mathrm{HCO}_{3}$ & & & & & & & 1.00 & 0.78 \\
\hline $\mathrm{CO}_{3}$ & & & & & & & & 1.00 \\
\hline
\end{tabular}

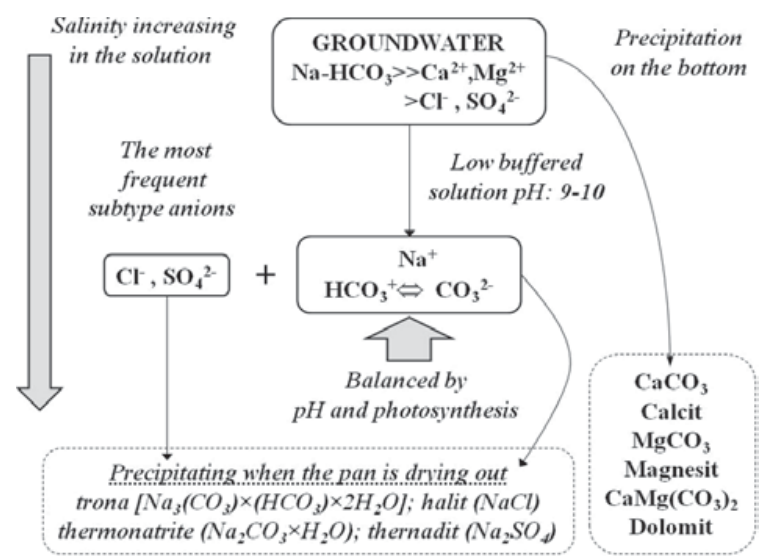

Fig. 4. The schematic presentation of the chemical genesis of alkaline soda pans in the Carpathian Basin (a simplified version after Grant, 2006).

environment in the Carpathian Basin. A similarly high diversity of soda affected alkaline soils of the Basin was also reported formerly (Várallyay, 1993).

While $\mathrm{pH}$ regularly shows close relationship with salinity in a soda lake during a whole season (Boros et al., 2008) we could not prove significant relations between ionic composition and $\mathrm{pH}$ on a large spatial scale. This contradiction can be explained by the effect of photosynthesis, as $\mathrm{pH}$ level is also regulated by the photosynthetic activity which may be related to the heterogeneity of other environmental factors on a large scale. The wide range of oxygen saturation was presumably also attributable to occasionally extremely high algal oxygen production and bacterial oxygen consumption. Besides, decomposition may also be faster at higher $\mathrm{pH}$ values (Krachler et al., 2009).

It is a well-known phenomenon that in most of the surface waters, photosynthesis of algae and submerged macrophytes can significantly modify the $\mathrm{pH}$ level, but seemingly it has less importance in the soda pans. A case study on a hypertrophic soda pan demonstrated extremely high diurnal oxygen saturation, while $\mathrm{pH}$ values (9.5-9.7) had minor fluctuation (Vörös and Boros, 2010). This can probably be a consequence of high correlation between $\mathrm{pH}$ and $\mathrm{HCO}_{3}+\mathrm{CO}_{3}$ concentration. Although the salinity of soda pans has a high seasonal variation, this has only minor impact on the ionic composition except for the proportion of the $\mathrm{HCO}_{3}$ and $\mathrm{CO}_{3}$ ions. (Dvihally, 1960).
This alteration does not change the basic chemical characteristic of soda pans.

Summarizing, we present a schematic illustration of the chemical genesis of alkaline soda pans in the Carpathian Basin (Fig. 4). While neutral salt lakes develop in the presence of high $\mathrm{Ca}$ levels, soda lakes and pans are dependent on low levels of $\mathrm{Mg}$ and Ca (Grant, 2006; Warren, 2006), due to $\mathrm{Na}-\mathrm{HCO}_{3}$ richness of the groundwater inflow. The low level of $\mathrm{Ca}$ ions results in a low-buffered solution (pH: 9-10) with the richness of sodium in the cation pool, as calcite, magnesite and dolomite precipitate out of solution onto the bottom. The $\mathrm{HCO}_{3}$ and $\mathrm{CO}_{3}$ regime is also balanced by $\mathrm{pH}$ and photosynthesis. The second most frequent anions can be chloride and sulphate. While salinity increases in the solution due to decreasing water level, soda crystals are formed. Among them, the most frequent ones are trona $\left[\mathrm{Na}_{3}\left(\mathrm{CO}_{3}\right) \times\left(\mathrm{HCO}_{3}\right) \times 2 \mathrm{H}_{2} \mathrm{O}\right]$ and thermonatrite $\left(\mathrm{Na}_{2} \mathrm{CO}_{3} \times \mathrm{H}_{2} \mathrm{O}\right)$. Additionally, depending on the proportion of chloride and sulphate, thernadit $\left(\mathrm{Na}_{2} \mathrm{SO}_{4}\right)$ and halit $(\mathrm{NaCl})$ crystals may also precipitate in the soda pans of the Carpathian Basin.

According to their special chemistry and biota, as well as the significant decline in their number and territory, soda pans are listed on Habitat Directive (92/43/EC) as "Pannonian steppes and salt marshes" with high protection priority in Natura 2000 network of the European Union. Recent studies demonstrated frequent occurrence of some new species of alkaliphilic microorganisms in this specific environment (Borsodi et al., 2005, 2008, 2011). Similar peculiar autochthonous microflora was described from soda lakes of the south eastern Transbaikal region (Kompantseva et al., 2007). Furthermore, a worldwide overview of alkaline environments and biodiversity demonstrated that soda lakes and pans contain alkaliphilic representatives of most of the main evolutionary and trophic groups of bacteria and archaea (Grant, 2006). Consequently, these unique natural attributes and high conservation priority have to promote further limnological research of the soda pans.

Acknowledgements. We are grateful to the staffs of the Hungarian National Park Directorates, the Hortobágy Environmental Association, Zoltán Ecsedi, Attila Pellinger, Balázs Németh, Anna Práger and Tibor Hadarics in Hungary, Alois Herzig, Richard Haider and Rudolf Schalli in Austria and 
László Szőnyi, Ottó Bitó, Attila Ágoston, Ottó Szekeres, Klára Szabados and László Galambos in Serbia for their valuable help in data service or during field work. The study was supported by the LIFE07NAT/H/000324 project.

\section{References}

Boros E., 1999. Ecological state of sodic water bodies in Hungary (in Hungarian with English summary). Acta Biol. Debr. Oecol. Hung., 9, 13-80.

Boros E. and Vörös L., 2010. Salinity and ion composition of the Hungarian sodic (soda) pans. (in Hungarian with English Abstract). Acta Biol. Debr. Oecol. Hung., 22, 37-51.

Boros E., Nagy T., Pigniczki Cs., Kotymán L., Balogh K.V. and Vörös L., 2008. The effect of aquatic birds on the nutrient load and water quality of soda pans in Hungary. Acta Zool. Acad. Sci. Hung., 54, 207-224.

Borsodi A.K., Micsinai A., Rusznyák A., Vladár P., Kovács G., Tóth E.M. and Márialigeti K., 2005. Diversity of alkaliphilic and alkalitolerant bacteria cultivated from decomposing reed rhizomes in a Hungarian soda lake. Microb. Ecol., 50, 9-18.

Borsodi A.K., Márialigeti K., Szabó G., Palatinszky M., Pollák B., Kéki Z., Kovács A.L., Schumann P. and Tóth E.M., 2008. Bacillus aurantiacus sp. nov., an alkaliphilic and moderately halophilic bacterium isolated from Hungarian soda lakes. Int. J. Syst. Evol. Microbiol., 58, 845-851.

Borsodi A.K., Pollák B., Kéki Z., Rusznyák A., Kovács A.L., Sproer C., Schumann P., Márialigeti K. and Tóth E.M., 2011. Bacillus alkalisediminis sp. nov., a novel alkaliphilic and moderately halophilic bacterium isolated from the sediment of extremely shallow soda ponds. Int. J. Syst. Evol. Microbiol., 61, 1880-1886.

Dinka M., Ágoston-Szabó E., Berczik Á. and Kutrucz Gy., 2004. Influence of water level fluctuation on the spatial dynamic of the water chemistry at Lake Fertö/Neusiedler See. Limnologica, 34, 48-56.

Donászy E., 1959. Das Leben des Szelider Sees. Akadémiai Kiadó Budapest, 425 p.

Dvihally Zs.T., 1960. Szikes tóvizek kémiai összetételének évszakos változásai. Hidrológiai Közlöny, 40, 316-323.

Eugster H.P. and Hardie L.A., 1978. Saline Lakes. In: Lerman A. (ed.), Lakes; Chemistry, Geology, Physics, Springer-Verlag, New York, NY, 237-293.

Freeze R.A. and Cherry J.A., 1979. Groundwater, Prentice-Hall, Englewood Cliffs, New Jersey, 15-29.

Grant W.D., 2006. Alkaline environments and biodiversity. In: Gerday C. and Glansdorff N. (eds.), Extremophilies, Encyclopedia of Life Support Systems (EOLSS), Developed under the Auspices of the UNESCO, EOLSS Publishers, Oxford, UK, http://www.eolss.net.

Hammer U.T., 1986. Saline Lake Ecosystems of the World, Dr W. Junk Publishers, The Hague, 616 p.

Horváth Zs., Vad Cs.F., Vörös L. and Boros E., 2013a. Distribution and conservation status of fairy shrimps (Crustacea: Anostraca) in the astatic soda pans of the Carpathian basin: the role of local and spatial factors. J. Limnol., 72, 103-116.

Horváth Zs., Vad Cs.F., Vörös L. and Boros E., 2013b. The keystone role of anostracans and copepods in European soda pans during the spring migration of waterbirds. Freshwater Biol., 58, 430-440.
Jambrina M., Armenteros I., Corrochano Á. and Recio C., 2013. Origin and hydrogeochemistry of a shallow flow-through lake on a Pleistocene piedmont, northern Spanish Meseta. J. Limnol., 72, 361-375.

Kompantseva E.I., Bryantseva I., Komova A.V. and Namsaraev B.B., 2007. The structure of phototrophic communities of soda lakes of the Southeastern Transbaikal Region. Microbiology, 76, 211-219.

Krachler R., Krachler R., Stojanovic A., Wielander B. and Herzig A., 2009. Effects of $\mathrm{pH}$ on aquatic biodegradation processes. Biogeosci. Discuss., 6, 13.

Löffler H., 1957. Vergleichende limnologische Untersuchungen an den Gewässern des Seewinkels (Burgenland). Verh. Zool. Bot. Ges. Wien, 97, 27-52.

Löffler H., 1971. Geographische Verteilung und Entstehung von Alkaliseen. Sitz. ber. Öst. Akad. Wiss., Math.-Naturwiss. Kl., Abt. I, 179, 163-170.

Löffler H. (ed.), 1979. Neusiedlersee: The limnology of a shallow lake in Central Europe, Dr. W. Junk Publishers, The HagueBoston-London, $507 \mathrm{p}$.

Maucha R., 1932. Hydrochemische Methoden in der Limnologie. Die Binnengewasser, Band 12, Schweizerbart'sche Verlagsbuchhandlung, Stuttgart, 173 p.

Megyeri J., 1979. A szikes tavak általános tulajdonságai. In: Tóth K. (ed.), Nemzeti Park a Kiskunságban, Natura, Budapest, 155-164.

Metz H. and Forró L., 1989. Contribution to the chemistry and crustacean zooplankton of sodic waters: the Seewinkel pans revisited. BFB-Bericht 70, Biologische Station Neusiedler See, Illmitz, 73 p.

Oberleitner I., Wolfram G. and Achatz-Blab A. (eds.), 2006. Salz Lebensräume in Österreich, Umweltbundesamt, Dessau, $216 \mathrm{p}$.

Petrović G., 1981. On the chemistry of some salt lakes and ponds in Yugoslavia. Hydrobiologia, 81, 195-200.

Schmidt A., 2003. Kiskunsági szikes tavak (KNP II) összehasonlító vízkémiai vizsgálata. Természetvédelmi Közlemények, 10, 153-162.

Szépfalusi J., 1971. Chemische Untersuchungen der Sodateiche im südlichen Teil der Großen Ungarischen Tiefebene. Math. - Naturw. Kl., Abt. I, 179, 205-223.

Várallyay Gy., 1993. Soil data bases for sustainable land useHungarian case study. In: Greenland D.J. and Szabolcs I. (eds.), Soil Resilience and Sustainable Land Use, CAB International, Wallingford, 469-495.

Vörös L. and Boros E., 2010. Nodularia willei Gardn. tömegprodukció: a planktonikus és bentonikus elsődleges termelés peremfeltételei egy kiskunsági szikes tóban (Kelemen-szék). Acta Biol. Debr. Oecol. Hung., 22, 139-152.

Warren J.K., 2006. Evaporites: Sediments, Resources and Hydrocarbons. Chapter 2: Depositional Chemistry and Hydrology, Springer-Verlag, Berlin, Heidelberg, 59-136.

Williams W.D., 1998. Guidelines of lake management. Volume 6. Management of Saline Waters. International Lake Environment Committee - United Nations Environment Programme, $108 \mathrm{p}$.

Wolfram G., Schagerl M., Donabaum K. and Riedler P., 2004. Untersuchung der räumlichen und zeitlichen Verteilung benthischer Evertebraten in den Salzlacken des Seewinkels und ihre Rolle als Nahrungsgrundlage für Wasservögel. Teil I: Abiotische Charakterisierung. Scientific report for the National Park Neusiedler See - Seewinkel, Wien, 107 p. 


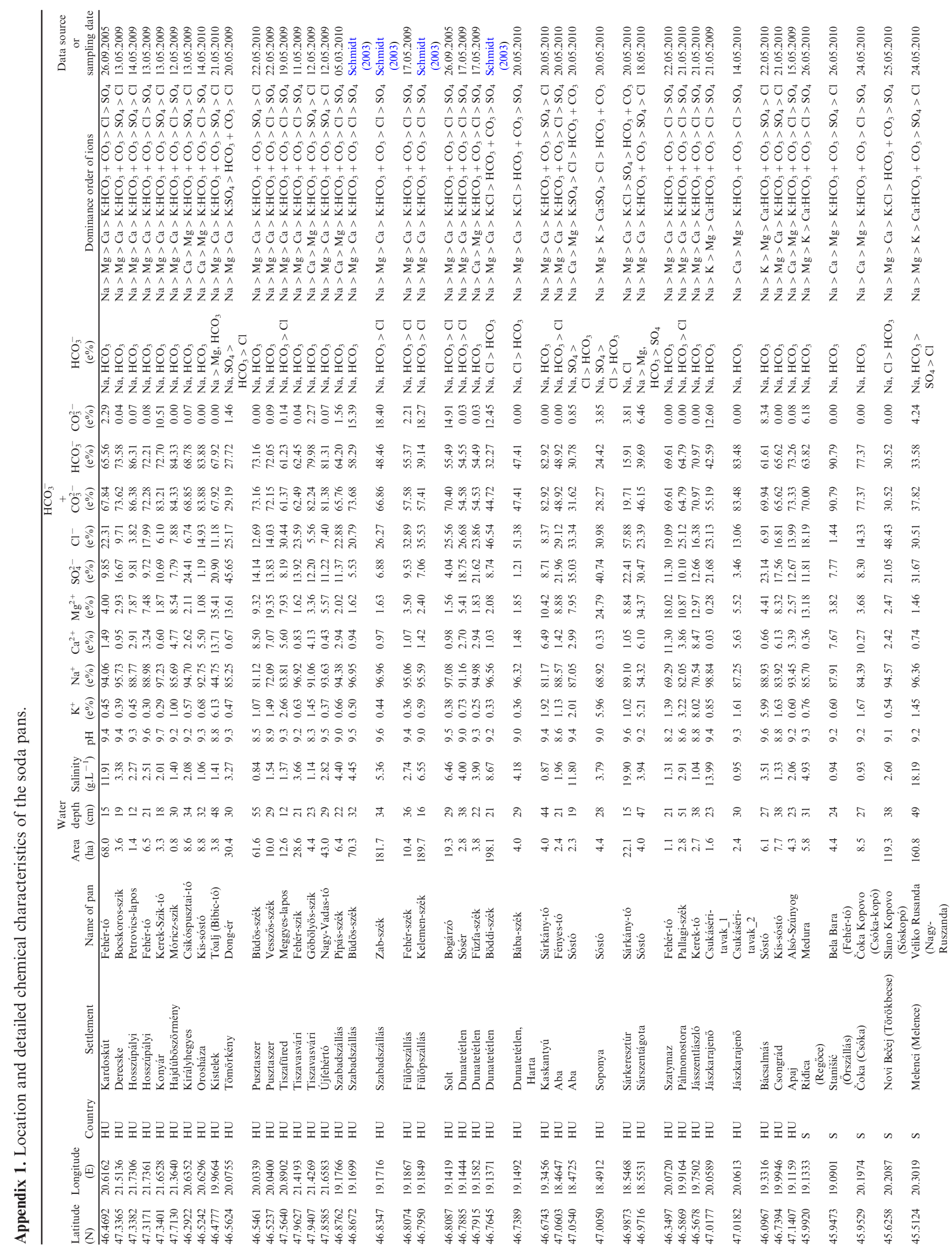




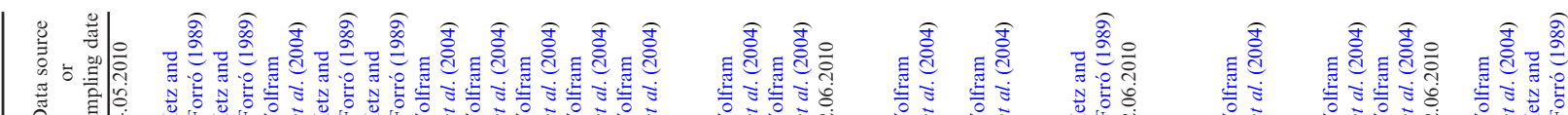

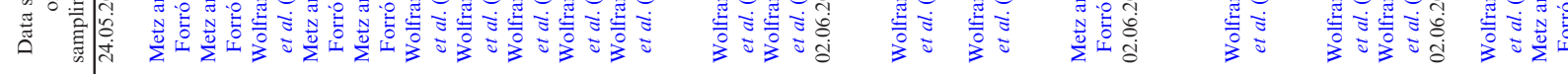

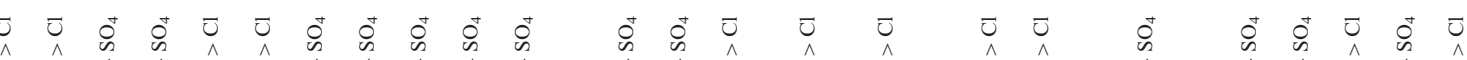

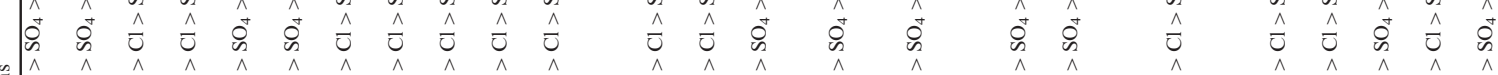
$\hat{c}$

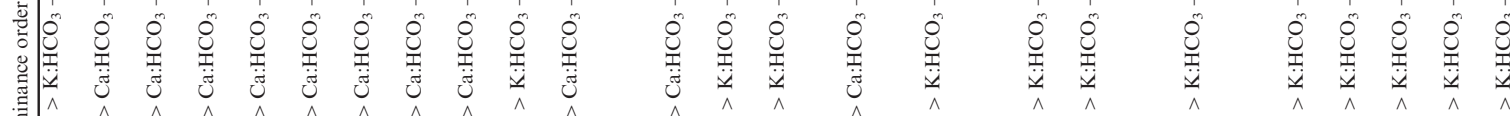

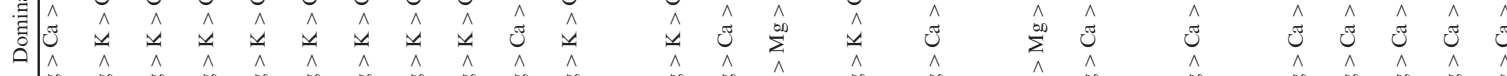

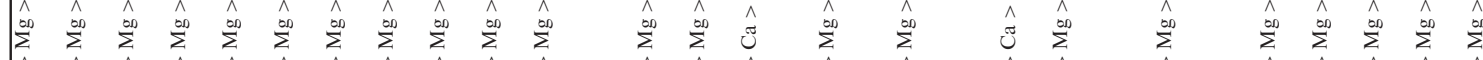

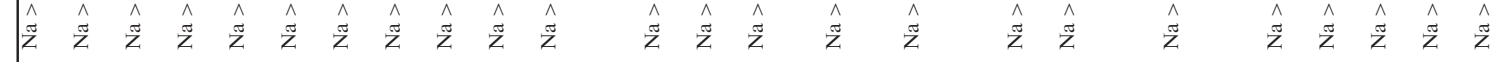

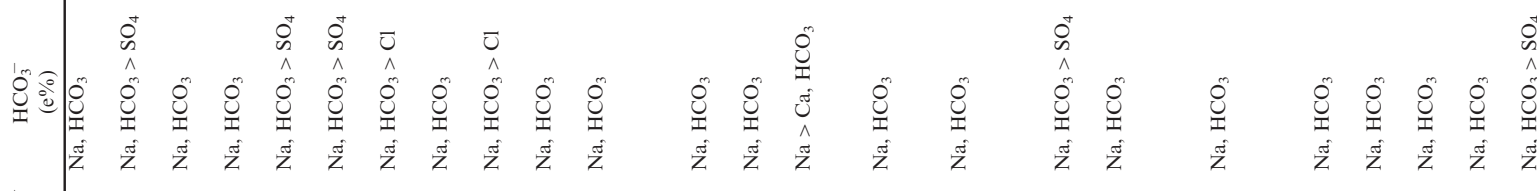

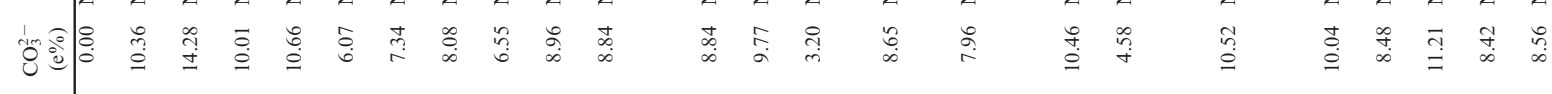

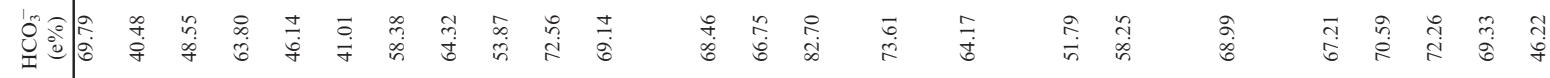

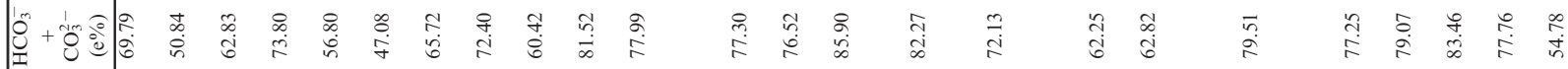

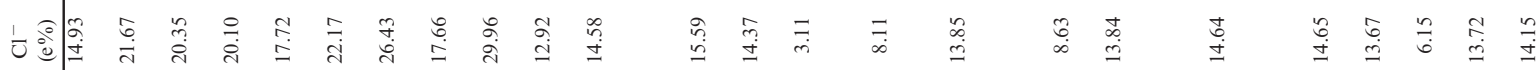

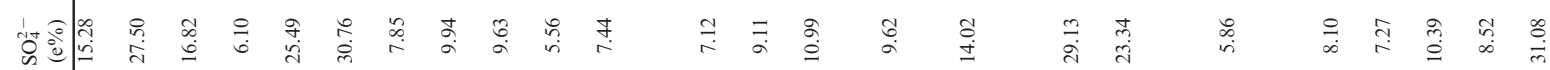

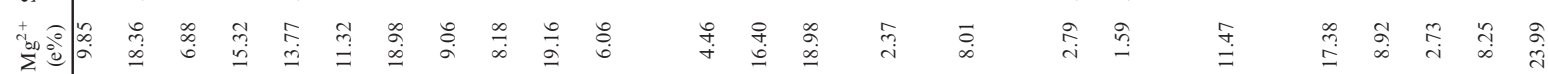

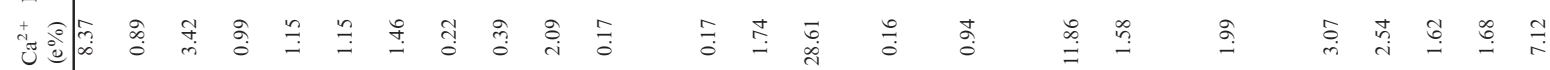

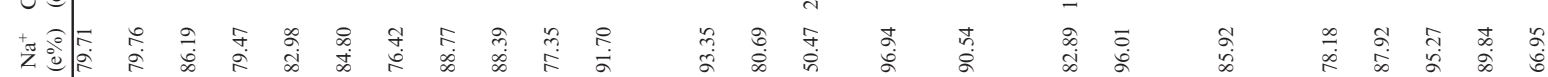

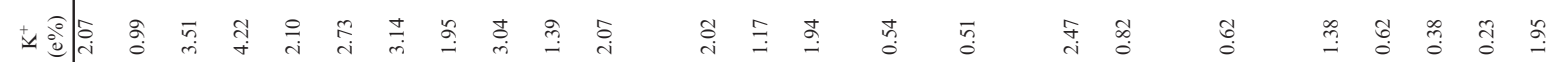

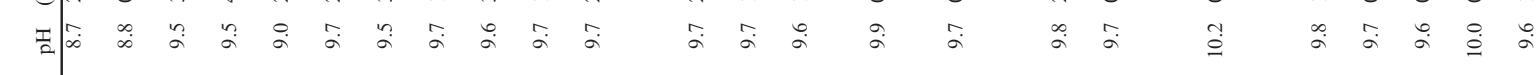

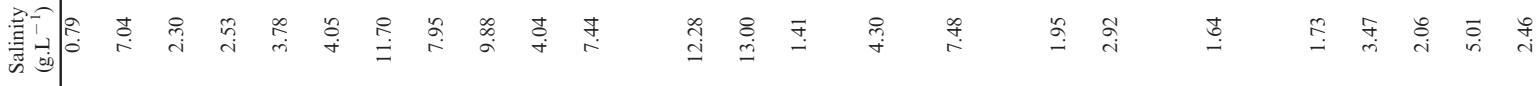

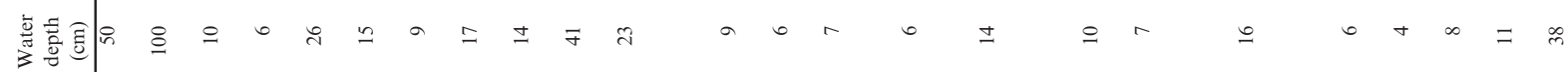

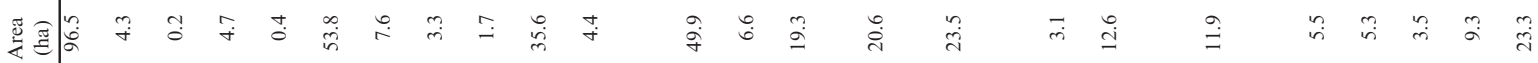

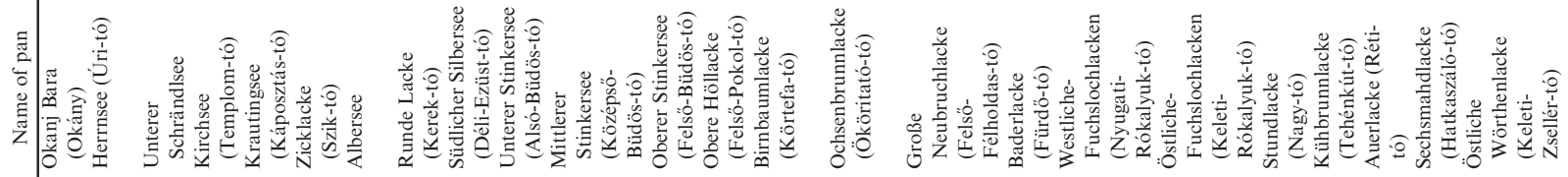

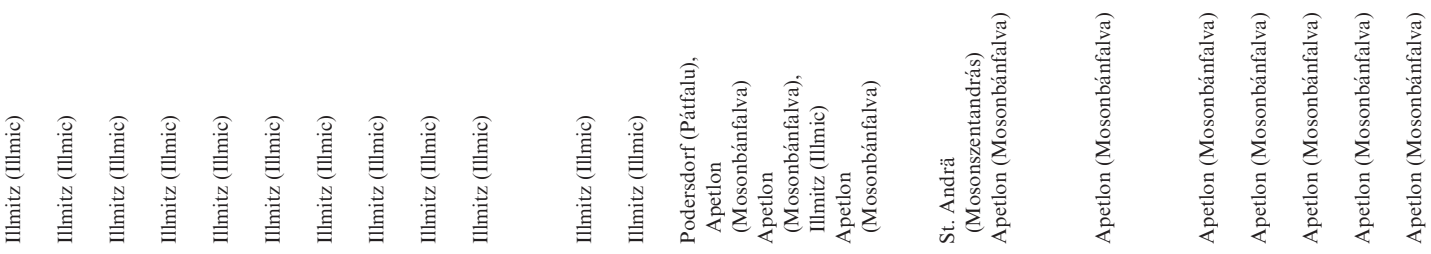
西 


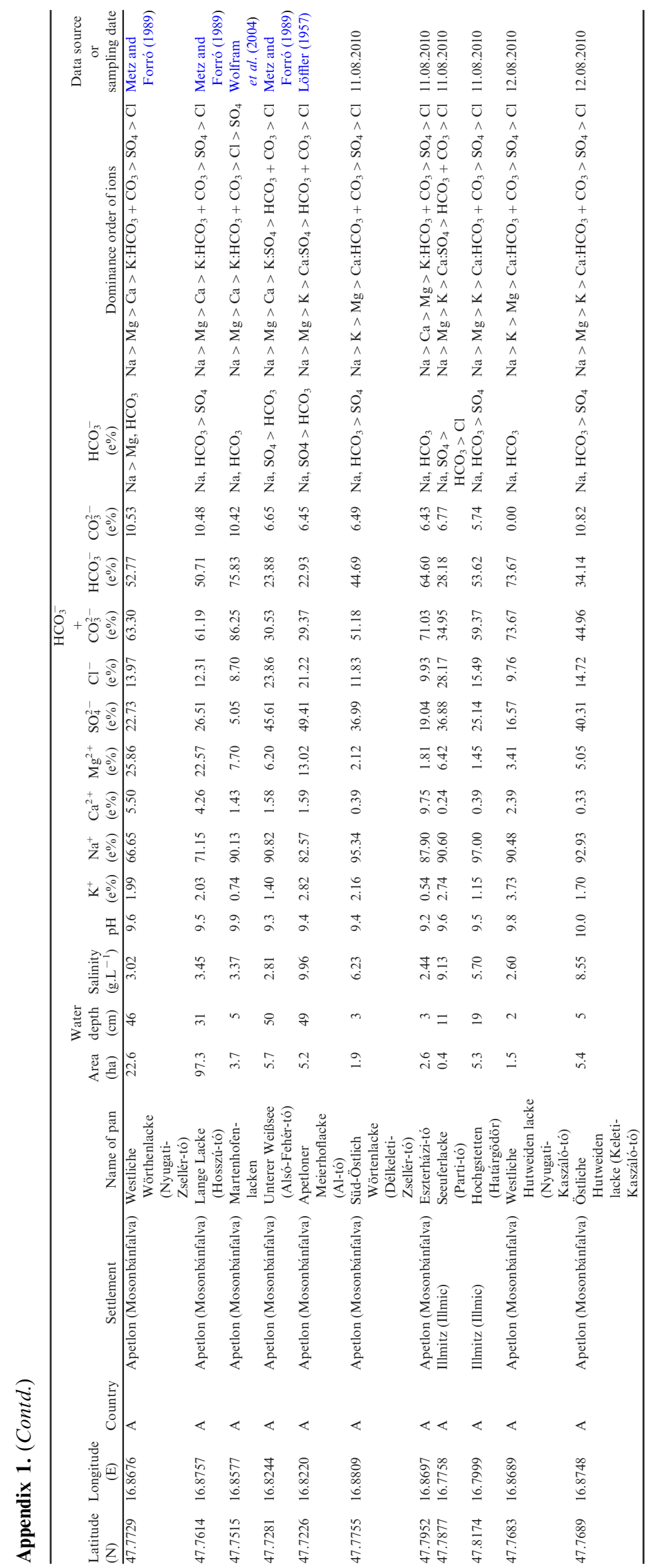

